\title{
Interactions of virulent and avirulent leptospires with primary cultures of renal epithelial cells
}

\author{
S. A. BALLARD, M. WILLIAMSON, B. ADLER, T. VINH and S. FAINE
}

Department of Microbiology, Monash University, Wellington Road, Clayton, 3168, Victoria, Australia

\begin{abstract}
Summary. A primary culture system for the cells of mouse renal-tubular epithelium was established and used to observe the adhesion of leptospires. Virulent strains of serovars copenhageni and ballum attached themselves to epithelial cells within $3 \mathrm{~h}$ of infection whereas an avirulent variant of serovar copenhageni did not adhere to epithelial cells at all within the experimental period of $24 \mathrm{~h}$. The saprophytic Leptospira biflexa serovar patoc became attached non-specifically to inert glass surfaces as well as to the cells. The adhesion of leptospires to epithelial cells was not inhibited by homologous antibody.
\end{abstract}

\section{Introduction}

The dissemination of leptospires in the urine of carrier animals is a critical factor in the epidemiology of leptospirosis. Leptospires survive in the renal proximal tubules, multiplying and colonising the tubular epithelium. The presence of specific antibody in the urine appears not to protect the host against the establishment or maintenance of the carrier state (Lane and Faine, 1963).

A frequent requirement for the establishment of infection is the ability of the causative microorganism to adhere to host-cell surfaces (Smith, 1977). In electronmicroscopic studies leptospires were observed in close association with the microvilli of proximal renal-tubular epithelial cells during chronic leptospirosis in hamsters (Miller and Wilson, 1967) and in sheep (Marshall, 1974). Colonisation of the renal tubules by leptospires is accompanied by their adhesion to the epithelial-cell surface.

Many workers have studied the interactions of leptospires with cultivated mammalian cells in attempts to relate cytotoxicity or adhesion of leptospires to pathogenesis. Leptospires caused visible cell damage in cultures of kidney cell lines (Finn and Jenkin, 1973) and in fibroblastic cell lines (Miller et al., 1970; Yam et al., 1970) in which adhesion to cell surfaces preceded cell damage (Vinh et al., 1984). However cytotoxicity was restricted neither to virulent strains nor to pathogenic serovars, saprophytic serovars being equally cytotoxic. This contrasts strikingly with the lack of cell damage observed by electronmicroscopy in

Received 18 Feb. 1985; accepted 25 Apr. 1985. epithelial cells of carrier animals (Miller and Wilson, 1967; Sterling and Thiermann, 1981). Thus it is difficult to assess the relevance of the in-vitro observations described above to pathogenesis of the chronic carrier state.

We wished to examine whether the ability of leptospires to adhere to renal epithelial cells might be related to virulence, to the ability to establish the carrier state, or to both. In this paper we report the interactions between leptospires and primary cell cultures of renal tubular-epithelial cells. Such cell cultures bear a closer resemblance than fibroblastic cell lines to the environment of leptospires in natural carriers.

\section{Materials and methods}

\section{Leptospires}

Leptospira interrogans serovar copenhageni $(45 \mathrm{H})$ and its avirulent variant (45S) were described previously (Faine and van der Hoeden, 1964), as were serovar ballum (17) and L. biflexa serovar patoc (41) (Adler and Faine, 1977). Leptospires were grown in EMJH medium with added pyruvate (Johnson et al., 1973) for 4-7 days at $30^{\circ} \mathrm{C}$ and counted by means of a Thoma bacterial counting chamber.

\section{Preparation of epithelial-cell monolayers}

Primary cell cultures of mouse renal-tubular epithelium were used because a renal carrier state is known to follow infection with leptospires in mice.

In each experiment, three Balb/c mice were killed by cervical dislocation, the kidneys removed aseptically and the renal cortices dissected out and diced finely. The 
cortical tissue was then mechanically minced on the surface of a $250-\mu \mathrm{m}$ stainless steel mesh by means of a stainless steel spoon; fragments were then washed through with tissue culture medium 199, $\mathrm{pH} 7 \cdot 4$, (M199; Commonwealth Serum Laboratories (CSL), Melbourne) containing $(/ \mathrm{ml})$ sodium bicarbonate $0.1 \%$, penicillin $\mathrm{G}$ 100 units, streptomycin sulphate $100 \mu \mathrm{g}$ and N-2-hydroxyethylpiperazine- $\mathrm{N}^{\prime}$-2-ethanesulphlonic acid (Hepes) $0.34 \mathrm{mg}$. The fragments of tubule in the filtrate were collected and further disrupted by mincing and washing through $184-\mu \mathrm{m}$ stainless steel mesh. In the final step the crude preparation of tubule fragments was washed through $103-\mu \mathrm{m}$ stainless steel mesh, which retained the tubule fragments but not unwanted single cells, glomeruli or cell debris. Tubule fragments were collected and resuspended in $12.0 \mathrm{ml}$ of M199 containing fetal calf serum (fcs; CSL) $20 \%$. One-ml volumes were dispensed into the wells of a tissue culture tray (Costar, Flow Laboratories) containing glass coverslips $(4 \times 5 \mathrm{~mm})$, and incubated at $37^{\circ} \mathrm{C}$ in $\mathrm{CO}_{2} 5 \%$ for 7-10 days.

\section{Stains}

Alkaline phosphatase stain. Epithelial cell monolayers were washed thoroughly with phospate-buffered saline $p \mathrm{H} 7.2$ (PBS), then fixed in acetone for $30 \mathrm{~min}$ at $4^{\circ} \mathrm{C}$. Fixed monolayers were stained by the method of Gomori as described by Bancroft (1967) and examined microscopically under bright field illumination with a Zeiss IM35 microscope.

Indirect immunofluorescent staining for actin filaments. Epithelial cell monolayers were fixed and stained as described by Vinh et al. (1984) with rabbit anti-actin serum and examined with a Zeiss IM35 microscope equipped with epifluorescence illumination.

\section{Co-incubation of leptospires and epithelial cell mono- layers.}

Five-day-old cultures of leptospires were centrifuged at $27100 \mathrm{~g}$ for $10 \mathrm{~min}$ and the supernates discarded. Pelleted leptospires were washed twice with M199 without antibiotics (M199w) and resuspended in M199w with fcs $20 \%$ at a concentration of $5 \times 10^{8}$ leptospires $/ \mathrm{ml}$ for phasecontrast and immunofluorescence microscopy or $8 \times 10^{8}$ leptospires/ml for scanning electronmicroscopy (SEM).

Seven-day-old epithelial-cell monolayers were washed three times with $\mathrm{M} 199 \mathrm{w}$ before being seeded with $1.0 \mathrm{ml}$ of leptospiral suspension. Infected cell monolayers were incubated at $37^{\circ} \mathrm{C}$ in $\mathrm{CO}_{2} 5 \%$ for $1,2,3,6$ or $24 \mathrm{~h}$; at the end of the experiment unattached leptospires were removed by washing the coverslips three times with PBS.

The effect of antibody on adhesion of leptospires to epithelial cells was examined by adding a subagglutinating concentration of homologous mouse antiserum to the leptospiral suspension immediately before it was used to seed cell monolayers. Titres of mouse antisera were determined by the microscopic agglutination test (MAT; Faine, 1982) modified to read a zero end-point. A dilution of antiserum twice that of the MAT titre was considered subagglutinating.

\section{Preparation of antisera}

Homologous rabbit antisera were prepared as described by Adler and Faine (1977). Homologous mouse antisera were prepared in Balb/c mice by intraperitoneal inoculation of $0.5 \mathrm{ml}$ of leptospiral culture $\left(5 \times 10^{8}\right.$ leptospires $/ \mathrm{ml}$ ) grown in protein-free polysorbate $60 / 40$ medium (Christopher et al., 1982). Mice received a similar booster injection after 7-10 days and were bled by cardiac puncture 7 days later.

\section{Phase-contrast microscopy}

Coverslips with islands of epithelial cells were inverted on to a microscope slide and the edges sealed with wax. Direct observations of the interaction of epithelial cells and leptospires were made by phase-contrast microscopy with a Zeiss IM35 inverted microscope.

\section{Immunofluorescence microscopy}

Infected epithelial-cell monolayers were fixed with $1 \%$ neutral buffered formalin for $1 \mathrm{~h}$ at room temperature. Coverslips were stained by indirect immunofluorescence as described by Vinh et al. (1984) and examined with a Zeiss IM35 microscope equipped with epifluorescence illumination.

\section{Scanning electronmicroscopy}

Monolayers were fixed in glutaraldehyde $4 \%$ in

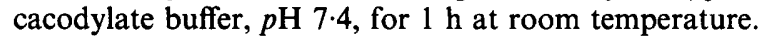
They were then given four washes in cacodylate buffer, $p \mathrm{H} \mathrm{7.4,} \mathrm{and} \mathrm{two} \mathrm{in} \mathrm{distilled} \mathrm{water} \mathrm{before} \mathrm{being} \mathrm{post} \mathrm{fixed}$ in osmium tetroxide $2 \%$ in distilled water for $30 \mathrm{~min}$ at room temperature. The coverslips were then washed four times with distilled water and dehydrated first in a series of increasing ethanol concentrations and then by two further treatments with absolute ethanol, each for $15 \mathrm{~min}$, and two treatments with $100 \%$ dry ethanol. All reagents had been filtered through a $0 \cdot 22-\mu \mathrm{m}$ membrane (Millipore) before use. The coverslips were dried in a critical point drying apparatus (Samdri, USA) and attached to aluminium stubs before being coated with gold by means of a Polaron 5000 Sputter Coater. Coverslips were then observed in a Cambridge 50 scanning electron microscope at $20 \mathrm{kv}$.

\section{Results}

\section{Preliminary cell-culture experiments}

Mouse renal tubule fragments, prepared as described, adhered to glass coverslips within 4 days. Epithelial cells grew radially in islands migrating from adherent fragments. Optimal numbers of 

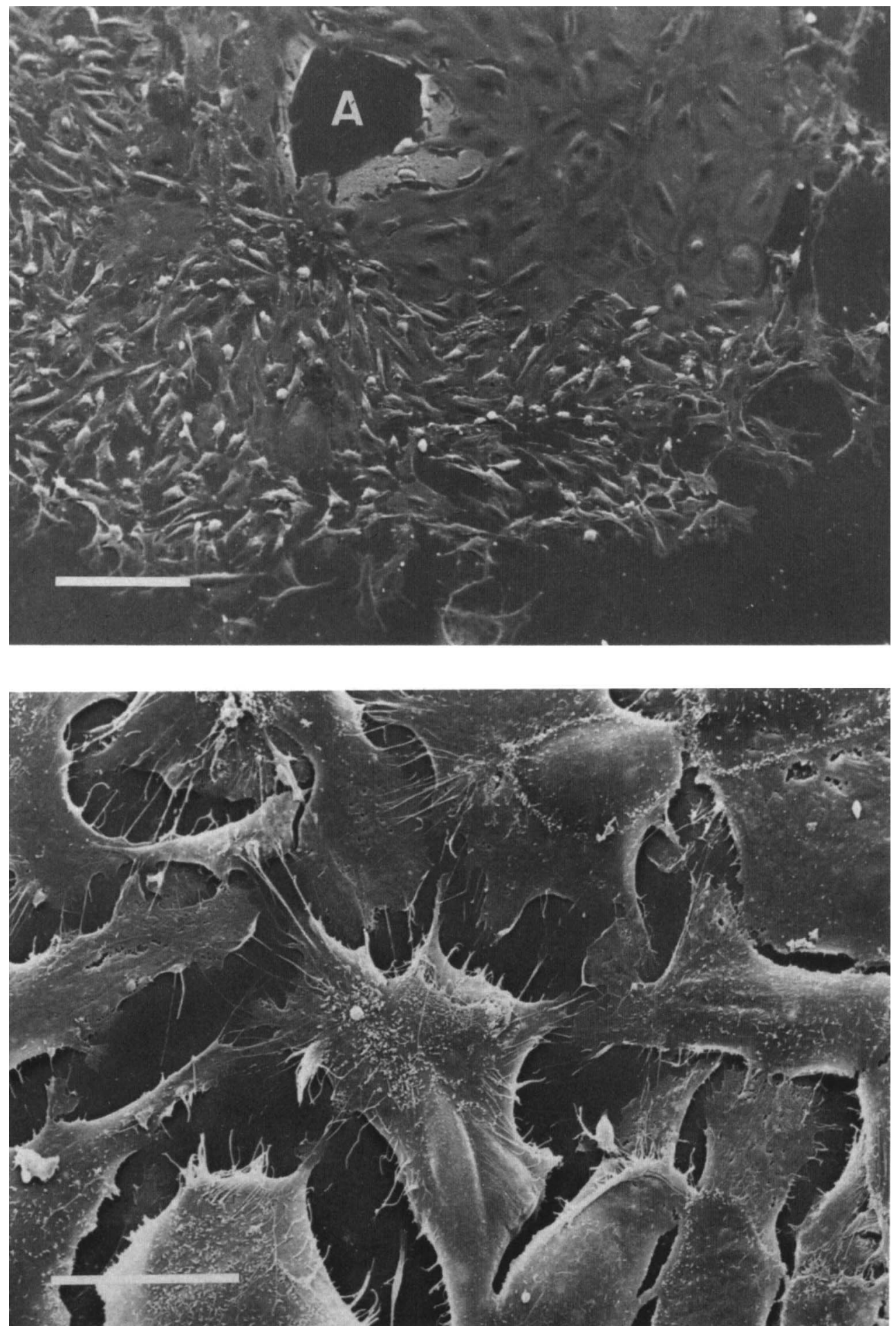

Fig. 1. Scanning electronmicrograph of epithelial cell growth derived from tubule fragment. Original site of tubule fragment (A). Bar $=200 \mu \mathrm{m}$ (top) and $20 \mu \mathrm{m}$ (bottom). 
epithelial cells for co-incubation experiments were found after 7-10 days in primary culture. After 10 days the cells began to deteriorate and slough off the coverslip.

The epithelial nature of the cell population was confirmed by histochemical staining for alkaline phosphatase. Cells reacted strongly after staining by the modified Gomori technique, indicating alkaline phosphatase activity. The absence of fibroblasts from the cultures were established by means of an immunofluorescent anti-actin stain.

Scanning electronmicroscopy of the islands showed variation in the size and morphology of cells (fig. 1). The cells adjacent to tubule fragments were closely packed and larger than those at the periphery of the island, which were small and slightly elongated with many filipodia. Microvilli were observed on the surface of both epithelial-cell types.

\section{Scanning electronmicroscopy (SEM)}

Attachment of the pathogenic $L$. interrogans serovar copenhageni $(45 \mathrm{H})$, its avirulent form (45S), serovar ballum and the non-pathogenic L. biflexa serovar patoc to renal tubular epithelial cells was investigated.

The virulent $45 \mathrm{H}$ strain of serovar copenhageni adhered to epithelial cells in very small numbers over a period of $24 \mathrm{~h}$. Leptospires attached themselves in discrete clumps to the cell surface and especially to the edges of peripheral epithelial cells (fig. 2). Few leptospires were observed to adhere to the large epithelial cells where filipodia and intercellular spaces were absent. The amount of adhesion was not proportional to the density of microvilli, but leptospires were rarely observed to adhere to epithelial cells without microvilli. The avirulent $45 \mathrm{~S}$ strain of serovar copenhageni did not adhere to epithelial cells at all, even after co-incubation for $24 \mathrm{~h}$.

Serovar ballum (fig. 3) adhered to the cell surface in clumps within $2 \mathrm{~h}$. The number of leptospires attaching appeared to increase with length of incubation, reaching a maximum after $c .6 \mathrm{~h}$.

In contrast serovar patoc attached indiscriminately to epithelial cells and to the glass coverslip. The leptospires attached "end-on" to the epithelial cells with only the occasional organism lying flat on the cell surface (fig. 3).

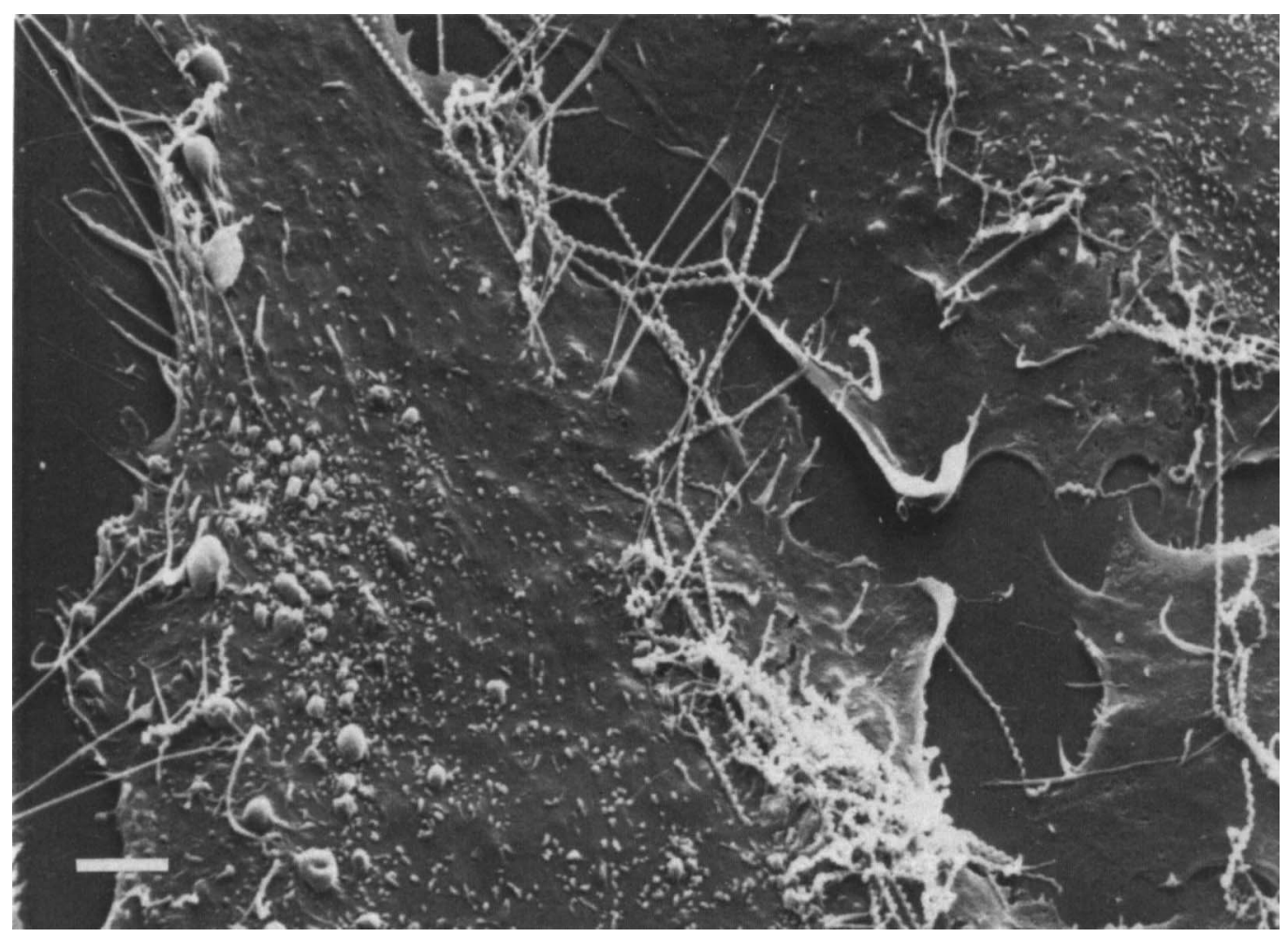

Fig. 2. Scanning electronmicrograph of epithelial cells $24 \mathrm{~h}$ after infection with virulent serovar copenhageni $(45 \mathrm{H})$. Bar $=4 \mu \mathrm{m}$. 

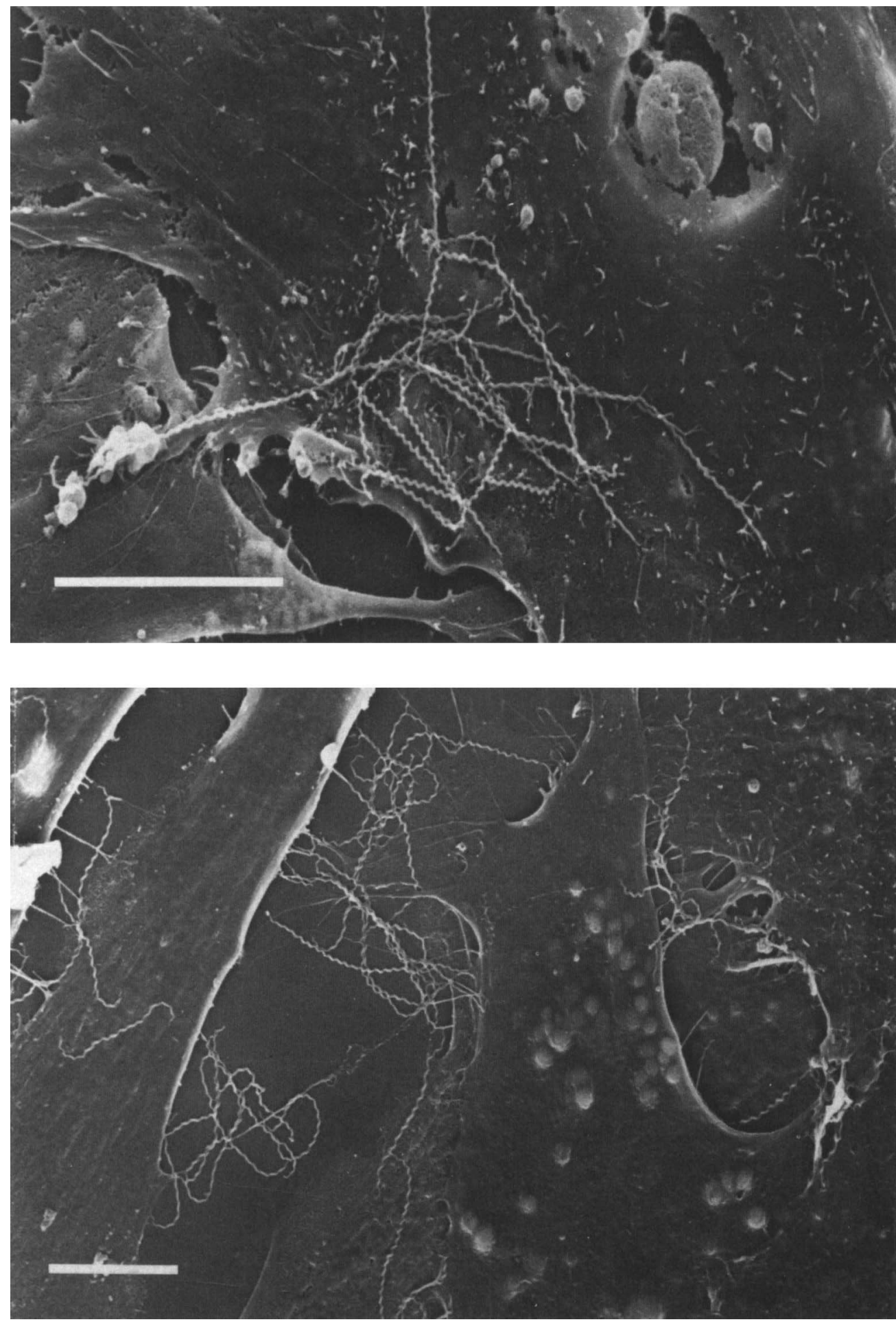

Fig. 3. Scanning electronmicrograph showing leptospires of serovar ballum attached to epithelial cells (top) and of serovar patoc attached non-specifically to glass surface as well as to cells (bottom). Bar $=10 \mu \mathrm{m}$. 


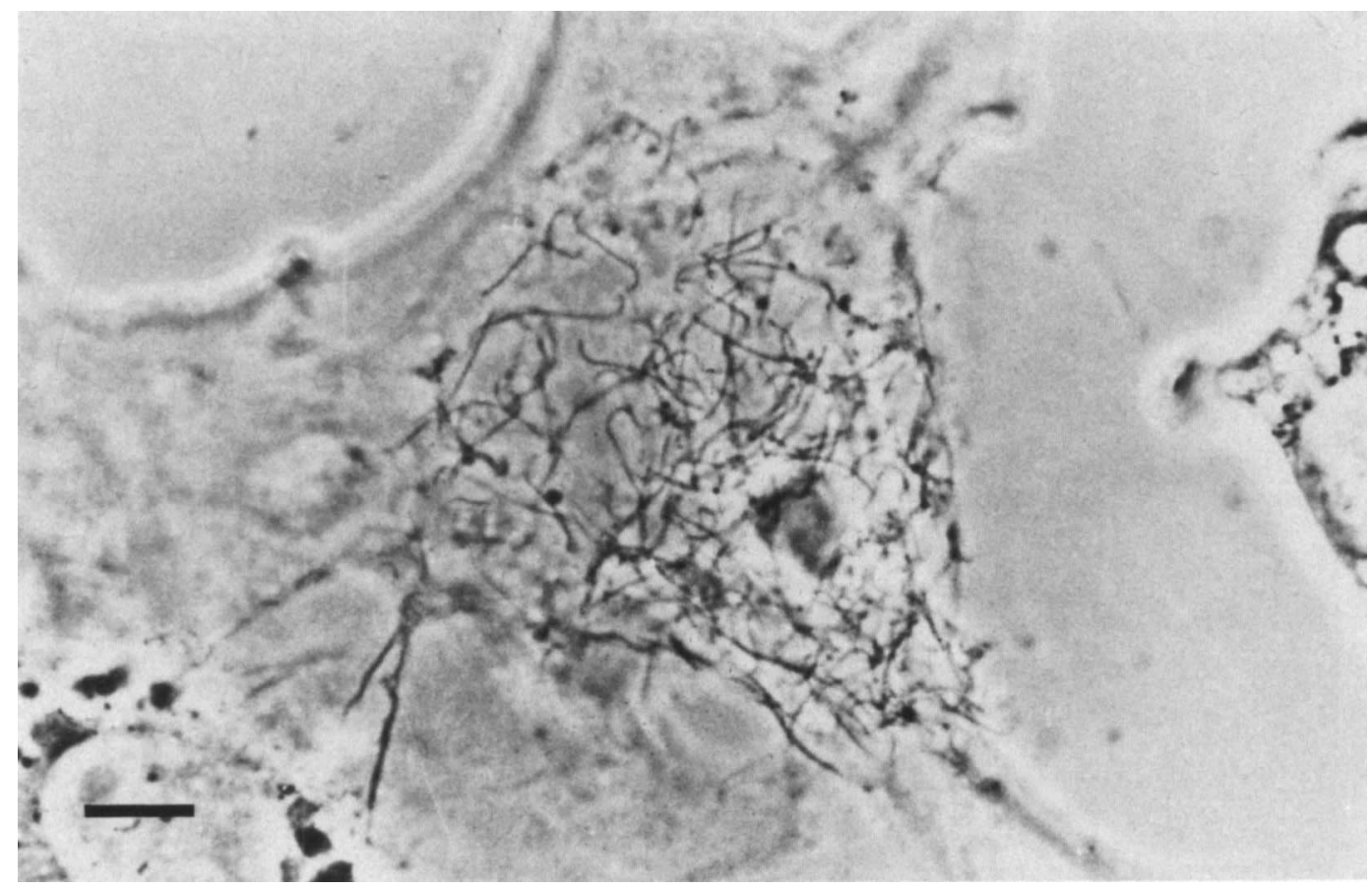

Fig. 4. Phase-contrast wet mount of leptospires of serovar ballum attached to epithelial-cell surface $2 \cdot 5 \mathrm{~h}$ after infection. Bar $=20 \mu \mathrm{m}$.

No evidence of epithelial-cell damage attributable to the presence of any of the leptospiral strains was observed.

\section{Phase-contrast and immunofluorescence microscopy}

Phase-contrast and immunofluorescence microscopy were used to investigate attachment of the two pathogens, serovar copenhageni $(45 \mathrm{H})$ and serovar ballum, and the non-pathogenic serovar patoc, to epithelial cells to compare with the observations made by SEM. The degree of adhesion to epithelial cells and the patterns of adhesion for serovars ballum, copenhageni and patoc were similar to those observed by SEM (fig. 4).

\section{Effect of homologous antibody}

The effect of homologous antibody prepared in mice on the attachment of leptospires to renal tubular epithelial cells was examined by SEM. A subagglutinating concentration of antibody had no observable effect on the attachment of serovar ballum or the avirulent strain $45 \mathrm{~S}$ of serovar copenhageni. However, higher concentrations of antibody resulted in the attachment of large agglutinated clumps of leptospires to the glass coverslip (fig. 5). In contrast, a subagglutinating concentration of homologous antibody enhanced the attachment of the virulent strain $45 \mathrm{H}$ of serovar copenhageni to epithelial cells. Leptospires were still observed to attach, in clumps, particularly to peripheral epithelial cells but in numbers significantly greater than those observed in the absence of antibody, especially during the first $3 \mathrm{~h}$ after inoculation. A subagglutinating concentration of antibody also enhanced the attachment of the nonpathogenic serovar patoc to the epithelial cells and to the glass coverslip.

Normal mouse serum was invariably without effect on the adhesion of leptospires. No cytopathic effect (CPE) on the epithelial cells was observed within $24 \mathrm{~h}$ when antiserum was present.

\section{Discussion}

Adhesion to various host tissues appears to be one of the many complex factors in microbial virulence. Tissue culture has proved useful in the study of host-parasite interactions because it is independent of host immunological factors. In this paper the interactions of leptospires with epithelial cells obtained by primary culture of mouse proximal tubule explants are reported. 

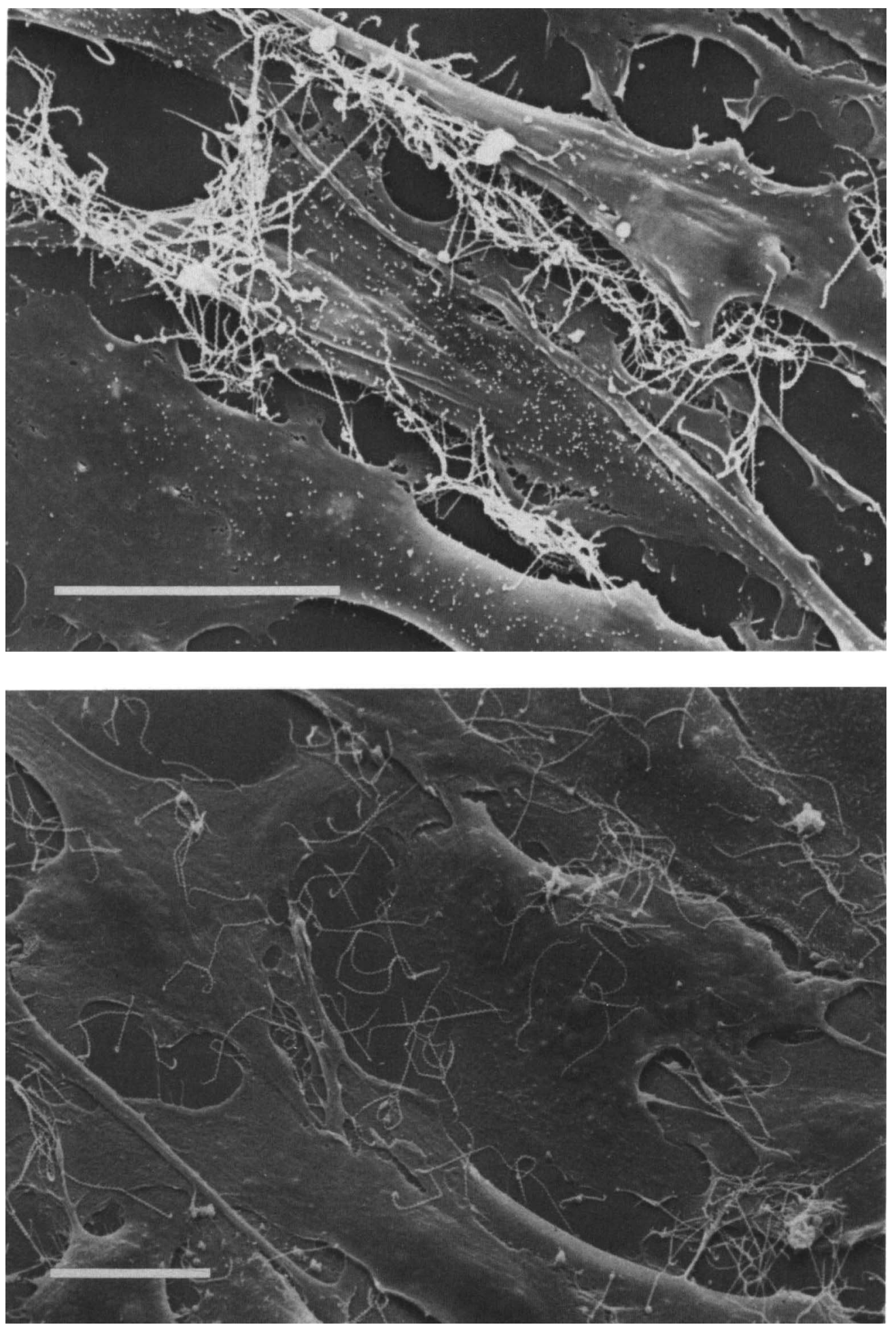

Fig. 5. Scanning electronmicrograph of leptospires of virulent serovar copenhageni (top) and patoc (bottom) incubated for $1 \mathrm{~h}$ with epithelial cells in the presence of subagglutinating concentrations of homologous mouse antiserum. $\operatorname{Bar}=20 \mu \mathrm{m}$. 
Unlike 72-h experiments with leptospires in fibroblast cultures (Vinh et al., 1984), our 24-h experiments in renal tubular epithelial cells showed no cytopathic effects attributable to the presence of virulent organisms. This is consistent with the lack of cell damage observed in epithelial cells of carrier animals (Miller and Wilson, 1967; Sterling and Thiermann, 1981) and other epithelial-cell cultures (Miller et al., 1966).

Two morphologically different cell types, both epithelial, were observed growing radially from the proximal tubule explants. The peripheral cells appeared to represent younger cells in an earlier stage of growth. Virulent leptospires from serovars copenhageni and ballum adhered particularly to the peripheral epithelial cells for reasons that are unclear, as is the significance of these observations for the renal carrier state.

A comparison of adhesion of virulent and avirulent strains of serovar copenhageni to epithelial cells suggests a correlation between virulence and adhesion. Vinh et al. (1984) demonstrated that avirulent copenhageni adhered less than virulent copenhageni to cultured L-cells. Moreover, Tsuchimoto et al. (1984) reported that virulent strains of serovars copenhageni, canicola and pomona readily attached to MDCK cells whereas avirulent strains of the same serovars attached poorly. Fitzgerald et al. (1977) found that large numbers of Treponema pallidum attached to cultured cells (epithelial and fibroblastic), but non-pathogenic treponemes failed to do so.

In view of the suggestion of a relation between virulence and adhesion in pathogenic leptospires, the non-pathogenic serovar patoc would not be expected to attach to epithelial cells in vitro. In this study, however, and throughout the literature, serovar patoc has been reported to attach in large numbers to cultured cell lines (Kefford, 1983; Vinh et al., 1984); this attachment may not be specific as the organisms also attach in large numbers to glass and plastic surfaces (Kefford and Marshall, 1984; Tsuchimoto et al., 1984; Vinh et al., 1984). Bacteria that adhere to inert surfaces do so non-specifically, by mechanisms that may also contribute to the adhesion of bacteria to eukaryotic cells (Marshall and Bitton, 1980). In such instances cultured epithelial or fibroblastic cell lines may merely act as another surface to which leptospires attach nonspecifically (Kefford, 1983). The attachment of saprophytic strains to cells is therefore irrelevant to studies of pathogenesis.

Specific antibody has been reported both to inhibit and to enhance leptospiral adhesion to host- cell surfaces in vitro, but the reasons for the various effects are unclear. Tsuchimoto et al. (1984) observed a decrease in the numbers of leptospires attaching to MDCK cells with increasing concentrations of Fab fragments of homologous IgG. In contrast Vinh et al. (1984) demonstrated enhancement of leptospiral adhesion to fibroblasts by subagglutinating amounts of homologous antibody.

In the present study the enhancing effect of specific antibody on the adhesion of leptospires to epithelial cells depended on antibody concentration. When agglutinating amounts of homologous antibody were used, all strains of leptospires aggregated into clumps and attached non-specifically and in large numbers to inert surfaces, reducing the numbers of organisms available for attachment to epithelial cells. When subagglutinating concentrations of homologous antibody were used to avoid this problem, they had no effect on the adhesion of serovar ballum or serovar copenhageni (avirulent strain) but enhanced specific adhesion of serovar copenhageni (virulent strain) and non-specific adhesion of serovar patoc.

In the carrier animal, antibody does not prevent the colonisation of the proximal tubules or shedding of organisms from the kidney (Faine, 1962). However, carrier animals frequently shed leptospires intermittently and this may in part reflect antibody inhibition or enhancement of leptospiral adhesion in the proximal tubules. Our observations suggest that varying concentrations of specific antibody can modulate adhesion of leptospires to the tubular epithelium.

In this paper we have established a culture system for renal epithelial cells, and shown that ability to adhere to these cells may be a necessary property of virulent leptospires, reflecting their behaviour in vivo. This system would provide a useful model for further study of the pathogenesis of leptospirosis if quantitative methods for measuring adhesion were to be developed.

This work was supported by a grant from the National Health and Medical Research Council, Canberra, Australia. We thank Associate Professor E. F. Glasgow, Department of Anatomy, Monash University for permission to use the Department's facilities and equipment for scanning electronmicroscopy, Dr W. Hancock, Prince Henry's Hospital, Melbourne, for assistance in the establishment of our cell-culture system and Associate Professor H. K. Muller, Department of Pathology and Immunology, Monash University, Melbourne, for the provision of rabbit anti-actin serum. We also acknowledge the excellent technical assistance of K. Hoe and C. Mayberry. 


\section{REFERENCES}

Adler B, Faine S 1977 Host immunological mechanisms in the resistance of mice to leptospiral infections. Infection and Immunity 17:67-72.

Bancroft J D (ed) 1967 An introduction to histochemical techniques, Butterworths, London.

Christopher W L, Adler B. Faine S 1982. Immunogenicity of leptospiral vaccines grown in protein-free medium. Journal of Medical Microbiology 15:493-501.

Faine S 1962 The growth of Leptospira australis B in the kidneys of mice in the incipient experimental carrier state. Journal of Hygiene 60:435-442.

Faine S 1982 Guidelines for the control of leptospirosis. World Health Organization Offset Publication No. 67, Geneva, p. 115.

Faine S, van der Hoedon J 1964 Virulence-linked colonial and morphological variation in Leptospira. Journal of Bacterio$\log y$ 88:1493-1496.

Finn M A, Jenkin H M 1973 Cytopathic effects of Leptospira serotypes patoc and canicola in three kidney cell culture systems. American Journal of Veterinary Research 34:669 672 .

Fitzgerald T J, Johnson R C, Miller J N, Sykes J A 1977 Characterization of the attachment of Treponema pallidum (Nichols strain) to cultured mammalian cells and the potential relationship of attachment to pathogenicity. Infection and Immunity 18:467-478.

Johnson R C, Walby J, Henry A, Auran N E 1973 Cultivation of parasitic leptospires: effect of pyruvate. Applied Microbiology 26:118-119.

Kefford B 1983 Implications of adhesion of leptospires at solidliquid interfaces, Ph.D. Thesis, University of New South Wales, p. 92.

Kefford B, Marshall K C 1984 Adhesion of Leptospira at a solidliquid interface: a model. Archives of Microbiology 138:84 88 .
Lane G K, Faine S 1963 Urinary antibody during renal damage due to leptospiral infection in mice. Journal of Infectious Diseases 113:110-112.

Marshall K C, Bitton G 1980 Microbial adhesion in perspective. In: Bitton G, Marshall K C (eds) Adsorption of microorganisms to surfaces, Wiley-Interscience, New York, p. 1.

Marshall R B 1974 Ultrastructural changes in renal tubules of sheep following experimental infection with Leptospira interrogans serotype pomona. Journal of Medical Microbiology 7:505-508.

Miller N G, Froehling R C, White R J 1970 Activity of leptospires and their products on $\mathrm{L}$ cell monolayers. American Journal of Veterinary Research 31:371-377.

Miller N G, Wilson R B 1967 Electron microscopic study of the relationship of Leptospira pomona to the renal tubules of the hamster during acute and chronic leptospirosis. American Journal of Veterinary Research 28:225-235.

Miller R E, Miller N G, White R J 1966 Growth of Leptospira pomona and its effect on various tissue culture systems. Journal of Bacteriology 92:502-509.

Smith H 1977 Microbial surfaces in relation to pathogenicity. Bacteriological Reviews 41:475-500.

Sterling C R, Thiermann A B 1981 Urban rats as chronic carriers of leptospirosis: An ultrastructural investigation. Veterinary Pathology 18:628-637.

Tsuchimoto M, Niikura M, Ono E, Kida H, Yanagawa R 1984 Leptospiral attachment to cultured cells. Zentralblatt für Bakteriologie, Mikrobiologie und Hygiene A258:268-274.

Vinh T, Faine S, Adler B 1984 Adhesion of leptospires to mouse fibroblasts (L929) and its enhancement by specific antibody. Journal of Medical Microbiology 18:73-85.

Yam P A, Miller N G, White R J 1970 A leptospiral factor producing a cytopathic effect on L cells. Journal of Infectious Diseases 122:310-317. 